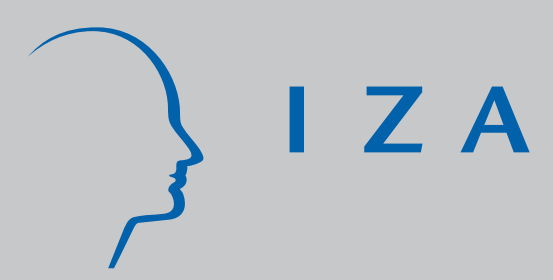

IZA DP No. 5885

Re-Visiting the Easterlin Hypothesis:

U.S. Fertility 1968-2010

Diane J. Macunovich

July 2011

Forschungsinstitut

zur Zukunft der Arbeit

Institute for the Study of Labor 


\title{
Re-Visiting the Easterlin Hypothesis: U.S. Fertility 1968-2010
}

\author{
Diane J. Macunovich \\ University of Redlands \\ and IZA
}

\section{Discussion Paper No. 5885}

July 2011

IZA

P.O. Box 7240

53072 Bonn

Germany

Phone: +49-228-3894-0

Fax: +49-228-3894-180

E-mail: iza@iza.org

Any opinions expressed here are those of the author(s) and not those of IZA. Research published in this series may include views on policy, but the institute itself takes no institutional policy positions.

The Institute for the Study of Labor (IZA) in Bonn is a local and virtual international research center and a place of communication between science, politics and business. IZA is an independent nonprofit organization supported by Deutsche Post Foundation. The center is associated with the University of Bonn and offers a stimulating research environment through its international network, workshops and conferences, data service, project support, research visits and doctoral program. IZA engages in (i) original and internationally competitive research in all fields of labor economics, (ii) development of policy concepts, and (iii) dissemination of research results and concepts to the interested public.

IZA Discussion Papers often represent preliminary work and are circulated to encourage discussion. Citation of such a paper should account for its provisional character. A revised version may be available directly from the author. 
IZA Discussion Paper No. 5885

July 2011

\section{ABSTRACT \\ Re-Visiting the Easterlin Hypothesis: U.S. Fertility 1968-2010}

This study tests the effect of relative income - younger people's earning potential relative to their aspirations, as approximated by older families' income - on two measures of fertility: the proportion of women with an own child under one year of age, and the proportion of women with at least one own child under eighteen. The results are highly supportive of the Easterlin relative income hypothesis, finding a dominant negative effect of older family income that extends due to postponement effects even into groups 11-15 years out of school. Increases in older family income are found to account for $42 \%$ of the decline in the proportion of women with a newborn, and $37 \%$ of the decline in the proportion with at least one own child, among women 0-5 years out of school. In addition, the study finds a strong but changing effect of the female wage: positive among women 0-5 years out of school, although slowly declining over time, but negative among the older women with a dominant positive time trend that has produced a positive effect in the last decade. It is hypothesized that the observed pattern of increases in fertility among women with higher levels of education over the last decade has been a function of this emerging positive effect of the female wage, among older more educated women.

JEL Classification: J13

Keywords: fertility, relative income, relative cohort size, Easterlin hypothesis

Corresponding author:

Diane J. Macunovich

Department of Economics

University of Redlands

Redlands, CA 92346

USA

E-mail: diane_macunovich@redlands.edu 
The Total Fertility Rate (TFR) in the U.S. generally increased from 1998 through 2007, until the beginning of the current Great Recession. It had risen to above-replacement level by 2006 - a level not seen in 35 years (National Vital Statistics Report, 2010). What factors might have produced this increase? Myrskyla, Kohler and Billari (2009) have suggested that advances in development (as measured by the Human Development Index) in more developed countries have helped in this reversal. But what aspects of development might have been at play, in what we think of as already "developed" economies? This paper suggests that the female wage has played a large part in the reversal, with its increases exerting a strong positive effect on women's fertility. This is in direct conflict with the "price of time" model (Mincer, 1963), which suggests that part of the "price" of children is the opportunity cost of the mother's time, so that the female wage should exert a negative effect on fertility. It is argued here that the increasing use - and acceptance - of paid childcare has removed this negative effect of the female wage, and has seen the emergence of a stronger - positive - "income effect" of the female wage on childbearing. The higher a woman's income, the more she is able to afford childcare - or to "buy back" time to be with her children.

Countering this positive effect, however, has been a strong negative effect of parental income, as first hypothesized by Richard Easterlin (1978). Easterlin postulated a systematic shift in preferences resulting from the fact that each successive generation, under economic development, experiences a successively higher parental standard of living. "In effect, a... 'subsistence level' constraint is added to the analysis of [fertility behavior] along with the budget line and production constraints." (Easterlin, 1978, and Ahlburg, 1984). Because of this 'subsistence level' constraint, economic or demographic fluctuations could cause periodic reversals in the secular downtrend in fertility, such as that observed in the developed countries in the postwar period - the "Baby Boom". In the full Easterlin model, relative birth cohort size (the size of one's birth cohort relative to the size of one's parents' birth cohort) inversely affects cohort earning potential relative to material aspirations, which in turn affects cohort fertility. 
According to the Easterlin theory, a large birth cohort meets unfavorable labor market conditions which reduce the earning potential of young males relative to their aspirations. In an attempt to close the gap between income and aspirations, members of such a cohort will tend to make a number of adjustments including increased female labor force participation and delayed/reduced marriage and childbearing. In addition, because young women in large cohorts will anticipate higher levels of labor force participation, they will tend to enroll in college at increased rates. In this formulation the driving force behind both increased female labor force participation and enrollments, and reduced fertility, is the desire of a large cohort to improve relative economic status, with parental income as the measure of that cohort's material aspirations.

\section{Literature Review}

Prior to the mid 1990s there was a plethora of studies on relative income and relative cohort size effects on fertility. Most of these were reviewed in Olsen (1994), Pampel and Peters (1995), and Macunovich (1998a). Olsen concluded that "the recent stability of the fertility rate suggests these theories do not have good short term predictive power." Similarly, Pampel and Peters found only a contingent effect on fertility at best. They concluded "the correspondence of the trends ends in the 1980s and appears in few countries other than the United States. Our review emphasizes both the contingent nature of the Easterlin effect and the way in which conditions have changed in recent decades to reduce the salience of cohort size for social and demographic behavior". However, Macunovich reviewed seventy-six published articles, concerned with both relative cohort size (RCS) and relative income (RY) effects on fertility, and found that an inordinate weight had been placed on the one-third with unfavorable findings. A number of problems were found in the studies, ranging from inappropriate formulations of a relative income variable, to the use of categorical rather than continuous variables, omitted variables, and inappropriate age groups.

In addition, Waldorf and Byun (2005) conducted a meta-analysis of 16 studies concerned with 334 estimated RCS effects on fertility, and found that just under half of them supported the Easterlin hypothesis, while only $13 \%$ found negative results - but that a larger proportion of the "favorable" studies 
were based on small sample sizes, than were the "unfavorable" studies. 38\% of the findings were insignificant. They found that the differences between findings resulted from age sensitivity of the RCS variable, the use of an (endogenous) income variable in the negative findings, and a publication bias against insignificant findings, toward positive findings in the earlier part of the period covered (19822002), and toward negative findings in the latter half. They found a disproportionate number of insignificant findings using European data.

Since the period covered by these reviews there have, to this author's knowledge, been eight analyses, all concerned with RCS effects on fertility. Macunovich (2000) found significant (negative) effects in a study of 184 developed and developing countries. In 2002, Waldorf and Franklin conducted a test both of spatial diffusion and the relative cohort size hypothesis using a cross-section time-series analysis of regions in Italy. They found that the data support the Easterlin hypothesis in terms of labor market movements, but not in terms of regional diffusion. McNown and Rajbhandary (2003) conducted a cointegration analysis of U.S. time series data for the period 1948-1997, and found support for the Easterlin hypothesis, in terms of RCS effects both on fertility (negative) and female labor force participation (positive). Jeon and Shields (2005) found support for the hypothesis using panel data for OECD countries 1975-1999. For Middle Eastern countries, Akin used an RCS variable in panel data, and found insignificant results. Sevilla (2007) found strong support using panel data for 90 developed and developing countries 1974-1994, with results equally strong for both groups. And Jeon and Shields (2008) found support using U.S. time series data covering the period 1913-2001. The most recent RY studies were conducted by Macunovich (1996, 1998b), both using U.S. time series data, and both with findings that supported the hypothesis. Similarly, Macunovich (2002) found highly significant effects in support of the hypothesis using more disaggregated data for the U.S.

\section{Relative Cohort Size, or Relative Income?}

It is to some extent not surprising that studies in the later 1980s and 1990s found insignificant or negative effects of relative cohort size on fertility, as indicated by Pampel and Peters, and by Waldorf and Byun. As Macunovich (1999) showed, the relationship between relative cohort size and relative wages is a 
complicated one, at least in the U.S., with less negative effects for those on the rising portion of a baby boom, and more negative ones on the declining side due to "bottleneck" and aggregate demand effects of relative cohort size. The bottleneck effect occurred because many young men entering the labor force when cohort size was increasing remained unemployed or underemployed, and they then competed for jobs that would otherwise have been taken by those in the smaller cohorts after the peak of the boom had passed. The aggregate demand effect is hypothesized to occur because increasing numbers of young people, in the household formation stage, increased the demand for durable goods thus spurring economic growth and the growth of wages. But after the peak of the boom, decline in the size of this young cohort dampened economic growth and the demand for labor - and hence the potential growth of young people's wages. Thus one would not expect relative income to rise in negative symmetry with its previous decline.

In addition - and perhaps even more significantly - in the U.S. after 1980, while relative cohort size was falling, older women's labor force participation, especially among married women with children, was rising quite dramatically. This had the effect of raising the older family income that forms the denominator of an RY variable much more sharply than it otherwise would have, thus dampening any increase in relative income that might have occurred as a result of changing RCS. In other words, the symmetry between RCS and RY - and hence fertility - was to a great extent destroyed in the 1980s and 1990s in the U.S., both through asymmetric effects of RCS, and rising female labor force participation. However, the relationship between RY and fertility might be expected to remain - as was demonstrated in Macunovich (1996, 1998b).

The problems of asymmetry between RY and RCS are illustrated in the graphs in Figures 1 and 2. Figure 1 illustrates two different relative measures, for young men in the first fifteen years out of school. Down the left hand side are relative wages - the average hourly wage of young men at each educational level, relative to the average hourly wage of older men with 25-34 years of work experience, with the same levels of education (roughly equivalent to men aged 45-54). This is the measure that Macunovich (1999) showed to be largely a function of RCS. Down the right hand side are relative incomes - the average wage of young men at each educational level, relative to the average family income of families with head 
of either sex aged 45-54 and the same level of education ${ }^{1}$. This latter measure is constructed in the spirit of Easterlin's relative income concept: a young person's earning potential relative to his aspirations. Superimposed on all the graphs is the inverted shape of the Total Fertility Rate (TFR) lagged 25 years - a measure of (inverted) RCS.

One can see in these graphs that the recovery of relative wages was much stronger after the peak of the Baby Boom had entered the labor market in the mid-1980s, than was the recovery of relative income. Older families' incomes - the denominator in the relative income variable - were rising too fast during this period, thanks to the entry of so many older women into the labor force. Younger males' wages couldn't keep up with that doubled rate of increase.

The differential is illustrated in Figure 2, which compares trends in the incomes of fathers aged 45-54, and the income of families with head of either sex aged 45-54. In all but the lowest education category ( $<12$ years), the gap between the two has widened significantly over the study period. Over all education levels, fathers' incomes increased by only 2.5\% between 1970 and 2010, from \$52,320 to \$53,620 in 2009 dollars, whereas family income increased by $30.4 \%$ during the same period, from $\$ 69,408$ to $\$ 90,522$. Between 1968 and 2010, older families' income increased by 44.6\% while fathers' income increased by only $12.7 \%$. This differential is the primary reason for the disconnect between RCS and RY, after the peak of the Baby Boom had entered the labor market.

\section{Measures of Relative Income ${ }^{2}$}

Easterlin (1987) has characterized his concept of relative income as (earnings potential)/(material aspirations). He operationalized this measure using "the recent income experience of a young man relative to the past income of the young man's parents." The concept is hypothesized to operate at the micro level; that is, young adults are assumed to set their desired standard of living based on the standard of living experienced in their own parents' homes.

\footnotetext{
${ }^{1}$ Family income in the denominator is in thousands.

2 This section is drawn largely from Macunovich (1996).
} 
However, there has been little research on the formation of material aspirations, so that the formulation of a relative income measure at the micro level is fraught with hazards. What is an appropriate relative income measure for an unmarried woman? And when looking at married couples, do we need a comparison of earnings of the husband or the wife, or both -- and relative to his parents, to her parents, or both? Not only have none of these questions been answered to date: in general we lack micro datasets which provide information on first and second generation income and fertility behavior for both partners in a union.

Thus any tests of the Easterlin Hypothesis at the micro level have either used gross proxies for the relative income measure (such as occupational data or responses to questions such as "How well-off are you?"-see MacDonald and Rindfuss, 1978), or used data only for the male in the couple, assuming that his preferences dominated in the household -- or they have done both. In addition, micro level formulations treat aspirations as being only a function of parental income, whereas it is likely that peer groups and other larger-scale social phenomena also operate on individual aspirations.

Such problems do not occur in more aggregate analyses. At the aggregate level we don't have to associate individuals with their own parents, or with their own spouses, but rather a young generation with its parental generation. We can use average household income in the parental generation as a measure of the average desired standard of living for both males and females in the younger generation, and this measure will better approximate both parental and other influences on a cohort's aspirations.

In addition, working at the aggregate level of analysis in a relative income context helps us address the problem of delayed/postponed marriage as it affects extra-marital fertility, since there has been a marked increase in the incidence of out-of-wedlock births. This makes it difficult to specify the effects of male relative income on females at the micro level. An aggregate relative income model of fertility accounts for such slippage, in that low male relative income prompts males to delay/postpone marriage, leaving more young women at risk of extramarital fertility. Incorporating the female wage in such an aggregate model, with allowance for its changing income effect, permits the female wage to exert the primary 
income effect on fertility in periods of low male relative income - as it would for a population containing large numbers of single women.

Macunovich (1996, 1998b) used U.S. national time series data for tests of Easterlin's relative income model, and this study follows suit but with much more disaggregated data - at the level of year-state-raceeducation-experience specific cells. It is assumed that fertility among individuals in the first fifteen years out of school will respond to parental income measured at their corresponding year-state-race-education specific level.

\section{A Look at the Rest of the Data}

What has been happening to the other variables of interest here - female wages and fertility itself?

Figure 3 is the female equivalent of Figure 1. That is, down the left side, by education level, is the starting wage of women relative to the average wage of men aged 25-34. Down the right side, by education level, is the starting wage of women relative to average family income in families with head of either sex aged $45-54^{3}$.

The figures down the left side suggest that young women's relative starting wage has been a close function of RCS over the years, like young men's average wage. This is particularly apparent for women with twelve or fewer years of education, where the pattern of their wage relative to the wage of men with 25-34 years' work experience conforms almost exactly to the shape of the inverted lagged Total Fertility Rate - even to the tailing-off since 2000. The starting wage is used here because women's wages are highly endogenous, depending on their continuity of work experience. So in the remainder of this study, only their starting wage will be used, to test its effect on fertility.

Down the right hand side of Figure 3, as on the right hand side of Figure 1, we see that women's starting wage has not performed as well relative to average older family income. Only for women with less than

\footnotetext{
${ }^{3}$ The average family income is in thousands.
} 
twelve years of education has there been a full recovery to pre-Baby Boom levels - even higher, in fact, since 2000.

Figure 4 presents patterns of two measures of fertility. On the left hand side we see the proportion of women with a newborn - a child under one year of age - by years out of school. On the right is the proportion of women with at least one child. The only really substantial increase since the mid-1970s has been among women 11-15 years out of school, although in general since 2000 there has been a noticeable increase for all women 1-15 years out of school. These are the two variables which will be modeled in this study.

\section{Data and Methodology}

The data are taken from the March Current Population Survey (CPS) for the years 1968-2010, as made uniform in CPS Utilities. All individual-level data has been aggregated into sex-year-state-raceeducation-experience cells ${ }^{4}$. Only currently unenrolled individuals were included in the analyses, and CPS weights were used in all cases. The CPS weights were normalized to sum to one in each year, in order to avoid giving any one year undue influence on the results. Analysis has been performed using Stata's "robust" OLS option that removes outliers ${ }^{5}$.

The assumption in all of these analyses is that the relative income comparison so difficult to quantify at the individual level using available data sources can be approximated using regional year-race-education level average parental income measures. Thus it is assumed that, all other factors held constant, young adults in a given year-state-race-education group with high parental income will feel relatively poorer than young adults where parental income in such a group is lower.

\footnotetext{
${ }^{4}$ Experience is measured as years out of school, using age-6-years of education. Only non-enrolled individuals are included in the analyses. The state groupings differ over the period, with 30 groups in the 1968-72 period, 23 in the 1973-76 period, and 51 from 1977 onward (including the District of Columbia). In all regressions, dummies for the 21 groups which have been common over all years, are included, together with dummies for years out of school.

${ }^{5}$ Standard errors were clustered at the state level in results available from the author, where results were very similar to those reported here.
} 
Two measures of fertility were used, both taken from the CPS: the proportion of women with a newborn an own child under one year of age - and the proportion with at least one own child under eighteen. Although the latter variable can increase with years out of school, this effect is controlled for by including "years out of school" dummy variables. Each variable was calculated in year-state-race-education-"years out of school" specific cells. CPS person-weights were used in calculating the proportions, and cell weights in estimating the regressions. The weights were all normalized to sum to one in each year, in order to avoid giving any one year too much influence on the estimates.

Average family income was calculated in year-state-race-education specific cells, using family weights. In 1976, where family weights were missing, all weights were set to one. Only families with head of either sex aged 45-54 were used in the calculations, under the assumption that this would be the age group most likely to have teenaged children. For young people 0-5 years out of school, this variable was lagged three years, under the assumption that this would approximate the time when individuals would have been most influenced by parental income. For those 6-10 years out of school the variable was lagged eight years, and for those 11-15 years out of school, it was lagged thirteen years.

Family income was topcoded to 1975 levels in 2009 dollars $\mathbf{( \$ 2 0 4 , 9 1 8 ) , ~ s i n c e ~ t h i s ~ w a s ~ t h e ~ y e a r ~ w h e n ~ C P S ~}$ topcodes were most restrictive. This involved at the most, 895 families out of 13,341 in 2009 and 844 out of 13,568 in 2010. In all other years it involved less than 500 families, and in most only about 200 families. However, for all topcoded families income was multiplied by a factor of 1.45, following on Blau and Kahn (2007).

Average male wages were calculated at the year-state-race-education-"years out of school" level, using CPS person weights, and calculated as total annual income from wages divided by total hours worked. Hours and weeks worked in the years prior to 1976 were allocated using an algorithm developed by Finis Welch (1979). Individuals were dropped from the analysis if the calculated wage was less than $\$ 2.50$ or more than \$250 per hour, in 2009 dollars (again following Blau and Kahn, 2007). The expected hourly wage was used: the estimated wage multiplied by the year-state-race-education-"years out of school" 
specific employment rate, to allow for local unemployment ${ }^{6}$. In matching male wage cells to the cell fertility proportions, a one-year gap was assumed between the ages of males and females, with the males one year older than the females, on average. In addition, the male wage was lagged one year to approximate the period of gestation. Quintiles of male wages were calculated by year and state, for estimating a possible differential effect of the female wage, depending on the level of male wages, as in Macunovich(1996, 1998b).

Only the average starting wage of women was used in the analysis (the wage of women 0-1 year out of school), because of the endogeneity of the female wage (that is, the wage can be affected by a woman's amount of participation in the labor force). Here again, hours and weeks worked prior to 1976 were allocated using the Welch algorithm, and individuals were dropped from the calculation if the hourly wage was calculated to be less than $\$ 2.50$ or greater than $\$ 250$ per hour, in 2009 dollars. CPS person weights were used in the calculation, and here again the female wage was lagged one year to approximate the period of gestation.

The models estimated were:

$$
\begin{aligned}
& \text { Newborn }_{k, t}=\beta_{0}+\beta_{1} W_{m, k+1, t-1}+\beta_{2} W_{f, t-1}+\beta_{3} F Y_{t-j}+\mathrm{B}^{\prime} X+u \quad k=0-15, t=1-42, j=3,8,13 \\
& \text { Prop_kids }{ }_{k, t}=\beta_{0}+\beta_{1} W_{m, k+1, t-1}+\beta_{2} W_{f, t-1}+\beta_{3} F Y_{t-j}+\mathrm{B}^{\prime} X+u \quad k=0-15, t=1-42, j=3,8,13
\end{aligned}
$$

where

$$
\begin{array}{ll}
\text { newborn }_{k, t}= & \begin{array}{l}
\text { proportion of women with an own child under one year old, } k \text { years out of school, in time } \\
\text { prop_kids }_{k, t}=
\end{array} \\
W_{m, k+1, t-1}= & \begin{array}{l}
\text { proportion of women with at least one own child under age eighteen, } k \text { years out of } \\
\text { school, in time } t
\end{array} \\
W_{f, t-1}= & \text { the average hourly wage of men } k+1 \text { years out of school, at time } t-1 . \\
F Y_{t-j} & \text { the average starting wage of women in time } t-1 \text {. }
\end{array}
$$

\footnotetext{
${ }^{6}$ The results using this expected wage were found to be very similar to those using the observed average wage, however.
} 
Each of the models was disaggregated at the state-race-education level. In addition, each model was estimated with an interaction term between the female wage and time, and interaction terms between the female wage and quintiles of the male wage, to test whether the effect of the female wage changes over time, and depending on the level of male wages, as found in Macunovich (1996, 1998b).

\section{Results: Proportion of Women with at Least One Own Child}

Table 2 presents results for the proportion of women with at least one own child under 18 . What comes across resoundingly in all of the results In Table 2 is the significant negative effect of older family income on this indicator of fertility. This is consistent with the Easterlin hypothesis, and the negative sign combined with the secular pattern of older family income shown in Figure 2 goes a long way toward explaining the general lack of recovery of fertility after the 1970s. In addition to being highly significant, the older family income variable displays a large standardized coefficient: in general, larger than any other coefficients apart from the positive ones for Blacks and for women with 8-11 years of education, and the negative ones for women with 16 or more years of education. The effect of older family income is largest for women 0-5 years out of school, but it remains significant even for those 6-15 years out of school, which makes sense if there is a cumulative effect of older family income on early fertility. For women $0-5$ years out of school, the elasticity with respect to older family income is 0.18 - thus given the 44.6\% increase in older family income between 1968 and 2010, this would account for $42 \%$ of the $19 \%$ drop in the proportion with at least one child, which occurred during this period.

Along with this effect of older family income, the effect of the female wage is most notable. Its effect is not significant until an interaction term with the time trend is added. Then, for women 1-15 years out of school over all, and for women 6-10 and 11-15 years out of school, its base effect is estimated to be significantly negative, but this effect is dominated by a highly significant positive effect of the time trend. The effect of the female wage has become increasingly positive over time. Combining the two nonstandardized coefficients for the female wage one finds that the negative effect declined rapidly, to the 
point where the total effect turned completely positive after 1998. The only exception is for women 0-5 years out of school: there, the basic effect is estimated to be positive (although significant only at the 13\% level) with an insignificantly negative time trend. If one takes into consideration the statistically insignificant negative time trend, it indicates that the effect of the female wage would not turn fully negative for this group until 2038. Thus, the estimates indicate that the effect of the female wage since at least 2000, for all women 0-15 years out of school, has been positive in terms of the proportion of women with at least one child. This positive effect is consistent with the increasing fertility that has been observed among older more educated women in the last decade (Vere, 2007).

When interaction terms between the female wage and male wage quintiles are added, we see that the effect is strongest when the male wage is lowest. For women $0-15$ years out of school over all, and for women 6-10 years out of school, there is a significant positive effect of the interaction with the first male wage quintile. For the other two groups, there are significant negative coefficients on the interactions with the fourth and fifth quintiles. This finding is in agreement with Macunovich (1996, 1998b): the positive effect of the female wage seems to be strongest when the male wage is low - its income effect is stronger there.

Surprisingly, the expected male wage (the average wage multiplied by the employment rate) in Table 2 is estimated to have a significant positive effect only for the fertility of women 0-15 years out of school over all. Thus the full effect of relative income as hypothesized by Easterlin - male earning potential relative to older family income as a measure of aspirations - dominates only if one considers the entire group 0-15 years out of school. The effect of the female wage relative to older family income appears to be more important than the effect of male relative income.

In terms of the other estimated effects in Table 2, the coefficient on the Black categorical variable is highly significantly positive for all but the 11-15 group. Similarly, the estimated effect is positive and highly significant for women with less than twelve years of education, with the effect strongest for 
women with 8-13 years of education. It is negative and significant for women with more than twelve years of education, with the effect by far largest for women with just sixteen years of education. It is notable that there is no significant time trend for women $0-5$ years out of school, with respect to the proportion having at least one child, once the other variables have been controlled for. There is, however, a negative trend for women 6-15 years out of school.

\section{Results: Proportion of Women with an Own Child Under One Year of Age}

Table 3 displays a more nuanced effect of older family income, for this measure of fertility. It has an overall significant negative effect for all women 0-15 years out of school, and a (larger) significant negative effect specifically for women 0-5 years out of school. Here again, for this younger age group, the standardized coefficient on older family income is large: comparable to those on the female wage variables. But the effect of older family income for women 6-10 years out of school, while negative, is not statistically significant, and it is positive but not significant for women 11-15 years out of school. These latter effects would be consistent with the idea of postponement due to the relative income effect: postponing at earlier ages due to low relative income leads to a positive effect at older ages. But the overall negative effect for the entire group 0-15 years out of school indicates that the postponement effect dominates: early postponement due to older family income lowers overall fertility. At 0-5 years out of school, the elasticity with respect to older family income is 0.19 - thus given the $44.6 \%$ increase in older family income between 1968 and 2010, this would account for 37\% of the $23 \%$ drop in the proportion of women with an own child under age one that occurred during this period.

The female wage for women 0-15 years out of school over all, and for women 6-10 years out of school, displays a negative and significant effect which is then overwhelmed by a positive time trend. Here again, as with the proportion of women with at least one child, the effect of the female wage is estimated to have turned completely positive after about 1998. This same pattern holds for women 11-15 years out of school, but is significant only at the $15-20 \%$ level. As in Table 2 the effect is reversed however for women 0-5 years out of school, where the basic estimated effect is positive, with a negative time trend 
that is barely significant at the $10 \%$ level. Here, the effect is estimated to have been positive until about 2008. The interaction terms between the female wage and male quintiles were not statistically significant for this measure of fertility, and thus have not been included in Table 3.

The male expected wage in Table 3 displays a significant positive effect only for women overall, and for women 11-15 years out of school. Here again, the ratio of the female wage to older family income appears to be stronger than that of the male wage to older family income.

In terms of the other variables in Table 3, the estimated coefficients on the Black categorical variable are negative and significant here, rather than the strong positive effect seen in Table 2. A similar turnaround is seen with the education dummies, for women 6-15 years out of school. The coefficients for women with 16 years of education are now positive, rather than the negative seen in Table 2, as are those for women with more than sixteen years of education, among women 6-10 years out of school. Only the positive coefficient for women 6-10 years out of school, with sixteen years of schooling, is statistically significant, however. This difference from Table 2 probably reflects the recent changes that have been noted elsewhere, of increasing fertility since 2000 among women with higher levels of education (Vere, 2007). Here again, as with the proportion with at least one child, it is notable that there is no significant time trend for women 0-5 years out of school once the other variables have been controlled for. There is, however, a negative trend for those who are 6-15 years out of school.

\section{Discussion}

Richard Easterlin in 1978 hypothesized that young people's fertility would be positively influenced by patterns of male relative income - the earning potential of young males relative to their aspirations, with their aspirations a direct function of their parents' income when they were growing up. This relative income was hypothesized to be, in turn, a negative function of the young people's relative cohort size the size of their own birth cohort relative to that of their parents' cohort. This was hypothesized to be due 
to imperfect substitutability between experience groups in the labor market, with an oversupply of young workers pushing down their wages relative to those of older workers - their own fathers, in effect.

Early studies for the most part supported these hypotheses, at least for the U.S., finding an inverse relationship between relative cohort size and fertility - but later studies were not so supportive. The graphs in this study indicate why this turnaround probably occurred. Male relative wages, hourly wage of young men relative to the hourly wage of men with 25-34 years' work experience, did indeed remain a function of relative cohort size - and this was supported by findings in Macunovich (1999). The theory of imperfect substitutability in the labor market appears to hold true. But male relative income, the hourly wage of young men relative to older family income, did not follow suit, and this appears to be a result of increasing female labor force participation - two-earner families pushing up family income relative to the earnings of the father alone. This increasing female labor force participation, however, has been shown to be a function of relative cohort size, as well, with younger women in the 1970s and 1980s entering the labor force to supplement the falling earnings of young men (McNown and Rajbhandary, 2003; Macunovich 1996), producing older two earner families in the last two decades. Thus what we have been observing has indeed all been a function of relative cohort size - but the relationship is more complex than was originally hypothesized, due to the labor force behavior of young mothers.

What this study has done, then, is to look directly at the effect of relative income on fertility, rather than at the effect of relative cohort size, since relative income is assumed to be the proximate determinant of young people's fertility. But such an analysis is made difficult by the fact that data on parental income certainly the income of both sets of parents for a partnership - is not collected in available data sets for the U.S ${ }^{7}$ So this study has approximated the relationship between young people and older family income by using more aggregated data - looking at young people in year-state-race-education-"years out of school" specific cells, and assuming that the behavior in these cells would be related to older family income in corresponding year-state-race-education specific cells. And instead of looking just at the

\footnotetext{
${ }^{7}$ An exception is the General Social Survey, which contains a categorical variable estimating whether the parental income when the respondent was 16 was "far below, below, average, above, or far above" average income. This variable may, however, be influenced by the respondent's own estimation of what was "average".
} 
youngest cohort of individuals - those just, say, 0-5 years out of school - this study has examined behavior in the entire group 0-15 years out of school, to trace longer-term effects of parental income.

Two measures of fertility have been used in the analyses: the proportion of women with an own child under one year of age, and the proportion of women with at least one own child under age eighteen. The results are highly consistent. They show a strong negative effect of older family income, and positive effect of the male wage, overall for women 0-15 years out of school. The negative effect on the proportion with newborns is more nuanced, however, in looking at three specific subgroups - those $0-5$, 6-10 and 11-15 years out of school. There is a strongly negative effect of older family income on those 05 years out of school, but this effect is insignificantly negative for those 6-10 years out, and insignificantly positive for those 11-15 years out - with both effects probably reflecting the result of postponement earlier on: postponement in the early years leads to higher fertility in later years. But the overall negative effect for the entire group 0-15 years out of school indicates that the postponement effect dominates: early postponement due to rising older family income lowers overall fertility.

The negative effect of older family income on newborns in the $0-5$ group obviously cumulates, then, so that in looking at the other fertility variable - the proportion with at least one child - there is a significant negative effect of older family income all the way up the line, in lagged form, even to those 11-15 years out of school. Thus the results provide strong support for Easterlin's relative income hypothesis.

Another finding is also notable, regarding the effects of the female wage. Only the starting wage is considered, given its endogeneity, and the results indicate its very strong effects. They are much stronger than those of the male wage, and the effects have been changing over time. For young women 0-5 years out of school they have been positive throughout the study period - both in terms of newborns and in terms of having at least one child - although there has been a weak negative time trend suggesting that this effect might have turned slightly negative in the last few years, in terms of newborns. In terms of having at least one child, the effect would not turn negative until well into this century (2038). For 
women 6-10 and 11-15 years out of school, however, the effect of the female wage on both measures of fertility started out negative, but is estimated to have turned positive by about 1998 . This is very consistent with the observed pattern of increases in fertility among women with more education and hence higher incomes, since about 2000 (Vere, 2007). The effect of higher levels of education on the proportions of women with newborns is estimated to be (insignificantly) positive, rather than negative as one might expect.

Thus we have two strong effects dominating the results with regard to both measures of fertility. One is a negative effect of older family income, as young people compare their own financial position to that of their parents and postpone or avoid children if they find themselves falling short. The other is a strong but changing effect of the female wage, with a positive but slowly declining effect among women 0-5 years out of school, and a negative effect among women 6-15 years out of school that has gradually turned positive since about 1998. So in terms of the above-replacement fertility we have observed in the U.S. over the past decade, then, it would seem that the rising position of women in society - and hence their rising wage - has to some small extent countered the negative effect of rising older family incomes. 


\section{Bibliography}

Ahlburg, Dennis A. (1984). "Commodity Aspirations in Easterlin's Relative Income Theory of Fertility," Social Biology, 31(3/4):201-207 (Fall).

Akin, MS (2005). Education and Fertility: A Panel Data Analysis for Middle Eastern Countries. The Journal of Developing Areas, 39(1):55-69.

Blau, Francine and L.M.Kahn (2007). "Changes in labor supply behavior of married women 1980-2000", Journal of Labor Economics, 25(31):393-438.

Easterlin, RA (1978). What Will 1984 Be Like? Socioeconomic Implications of Recent Twists in Age Structure@, Demography, 15(4 Nov): 397-432.

Jeon, Y and M Shields (2005). The Easterlin Hypothesis in the Recent Experience of Higher-Income OECD Countries: A Panel-Data Approach, Journal of Population Economics, 18:1-13.

Jeon, Y and M Shields (2008). The Impact of Relative Cohort Size on U.S. Fertility 1913-2001. IZA Discussion Paper 3587.

MacDonald, M M and RR Rindfuss (1978). "Relative Economic Status and Fertility: Evidence from a Cross-section," in Research in Population Economics, Vol. 1, Julian Simon, ed., JAI Press:Greenwich, CT.

Macunovich, DJ (1996). Relative Income and Price of Time: Exploring Their Effects on U.S. Fertility and Female Labor Force Participation, in Fertility in the United States: New Patterns, New Theories, Population and Development Review, supplement to Volume 22(1996):223-257.

Macunovich, DJ (1998a). Fertility and the Easterlin Hypothesis: An Assessment of the Literature, Journal of Population Economics, 11(1998):1-59.

Macunovich, DJ (1998b). Race and Relative Income/Price of Time Effects on U.S. Fertility, Journal of Socio-Economics, 27(3, 1998):365-400.

Macunovich, DJ (1999). The Fortunes of One’s Birth: Relative Cohort Size and the Youth Labor Market in the U.S. Journal of Population Economics, 12(2):215-272.

Macunovich, DJ (2000). Relative Cohort Size: Source of a Unifying Theory of Global Fertility Transition? Population and Development Review, 26(2):235-261.

Macunovich, DJ (2002). Birth Quake: The Baby Boom and Its Aftershocks. University of Chicago Press, Chicago.

McNown, R and S Rajbhandary (2003). Time Series Analysis of Fertility and Female Labor Force Behavior, Journal of Population Economics, 16:501-523.

Mincer, J (1963). "Market Prices, Opportunity Costs, and Income Effects" in Measurement in Economics. Studies in Mathematical Economics and Econometrics in Memory of Yehuda Grunfeld, C.F. Christ, M. Friedman, L.A. Goodman, Z. Griliches, A.C. Harberger et al., eds., Stanford, CA: Stanford University Press, 67-82.

Myrskyla, M, H-P Kohler and FC Billari (2009). Advances in Development Reverse Fertility Declines", Nature, 460(6 August):741-743. 
National Vital Statistics Report (2010). "Births: Final Data for 2008", 59(1), December.

Olsen, Randall J. (1994). "Fertility and the Size of the U.S. Labor Force", Journal of Economic Literature, XXXII(1):60-100.

Pampel, FC and HE Peters (1995). The Easterlin Effect, Annual Review of Sociology, 21(1995):163-194.

Sevilla, J (2007). Fertility and Relative Cohort Size Effects, Institute for Futures Studies 2007:11.

U.S. Department of Commerce, Bureau of the Census (2010). "Current Population Survey, March Supplement", as prepared by the Unicon Corporation in CPS Utilities.

Vere, JP (2007). 'Having It All' No Longer: Fertility, Female Labor Supply, and the New Life Choices of Generation X. Demography, 44(4):821-828.

Waldorf, B and R Franklin (2002). Spatial Dimensions of the Easterlin Hypothesis: Fertility Variations in Italy. Journal of Regional Science 42:549-578.

Waldorf, B and P Byun (2005). Meta-analysis of the Impact of Age Structure on Fertility, Journal of Population Economics, 18:15-40.

Welch F (1979) Effects of Cohort Size on Earnings: the Baby Boom Babies= Financial Bust. Journal of Political Economy 87(5,pt.2):S65-S97. 

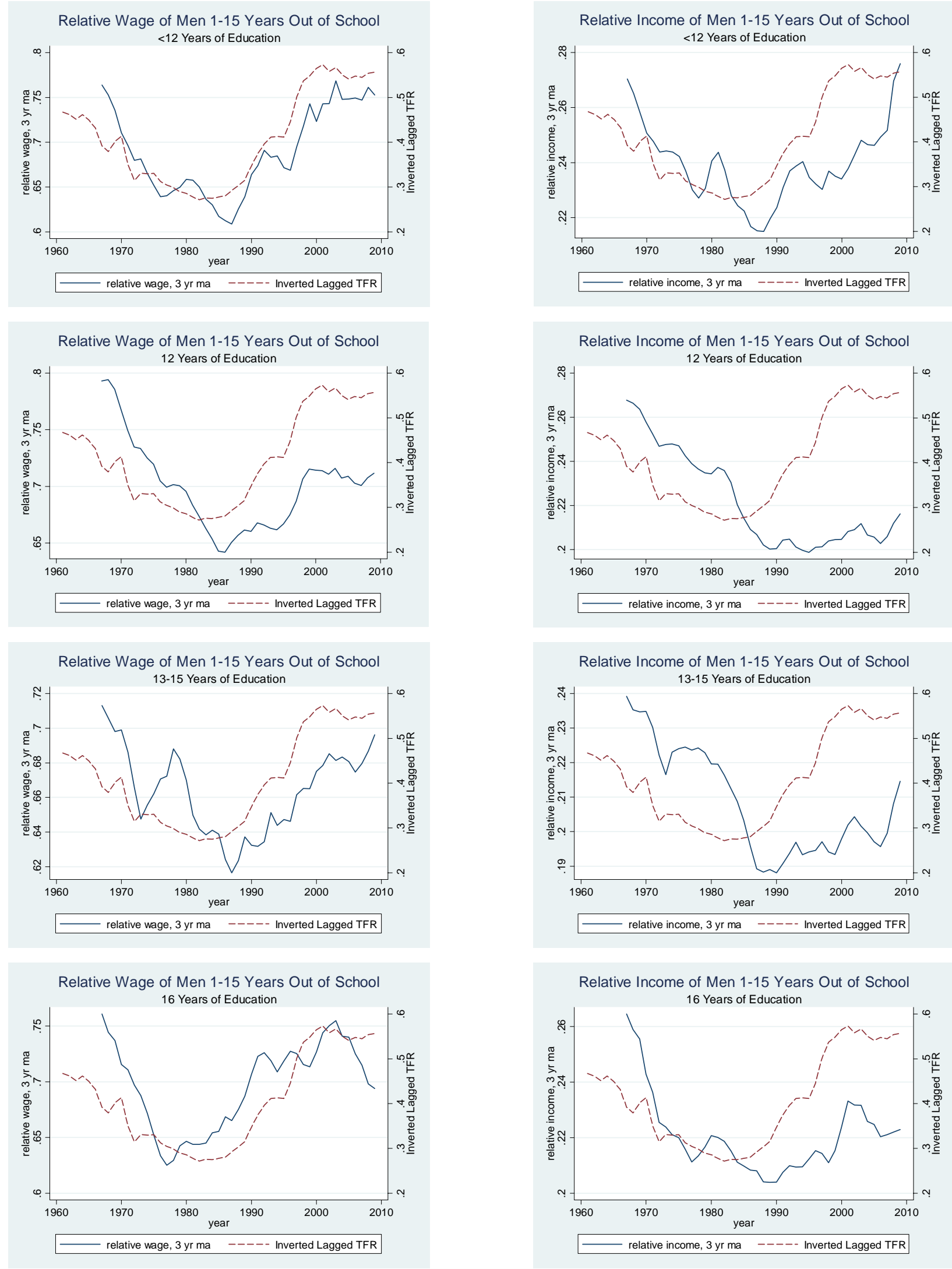

*Relative wage is the hourly wage of younger men relative to the hourly wage of men with 25-34 years of work experience. Relative income is the hourly wage of younger men relative to the income of families with head of either sex aged 45-54. Family income is in thousands. 
Figure 2: Comparison of Trends in Fathers' and Families' Income (3-yr moving averages)
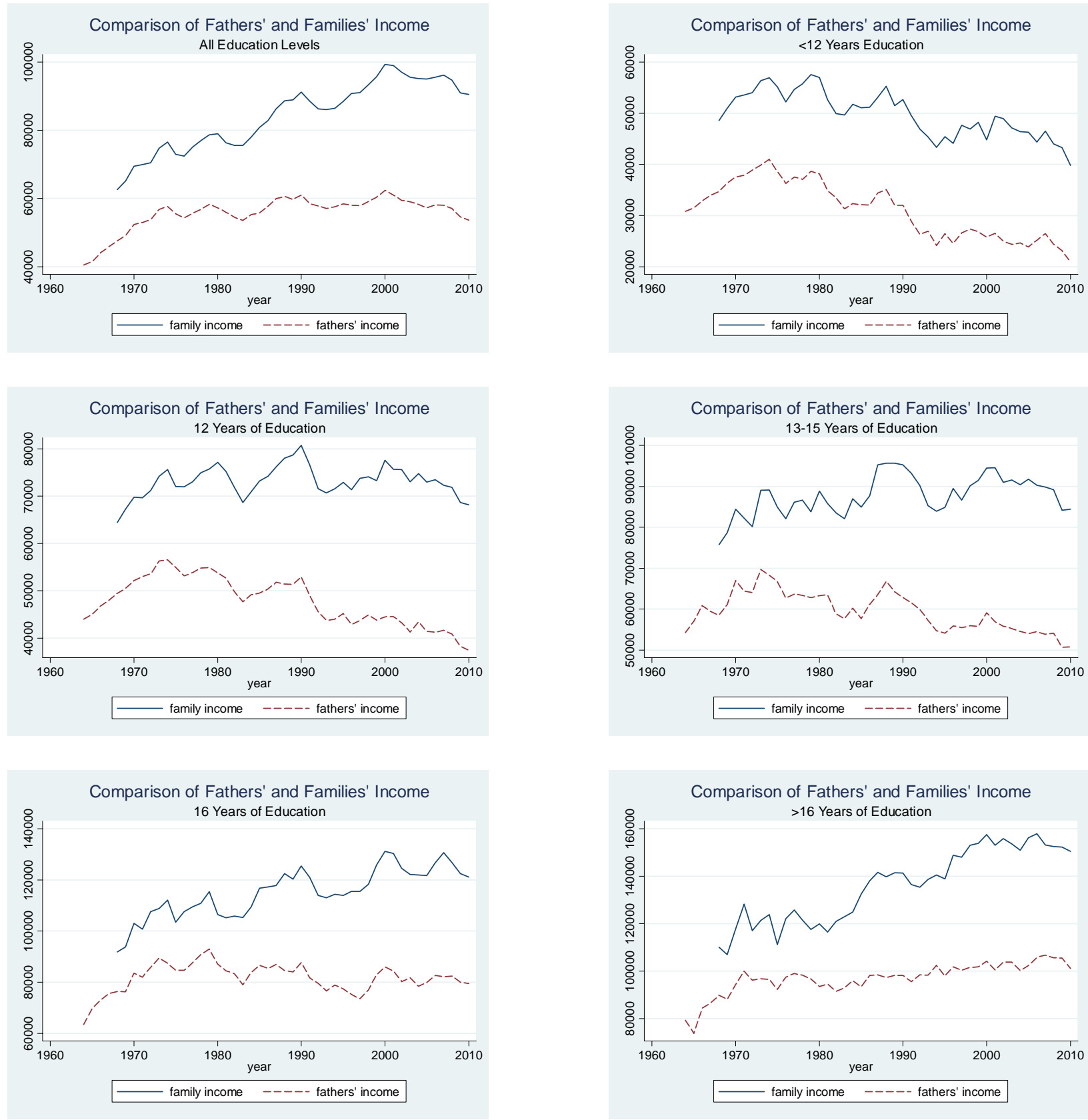
Figure 3: Women's Starting Wage Relative to the Wage of Men with 25-34 Years' Work Experience (3-yr moving averages)
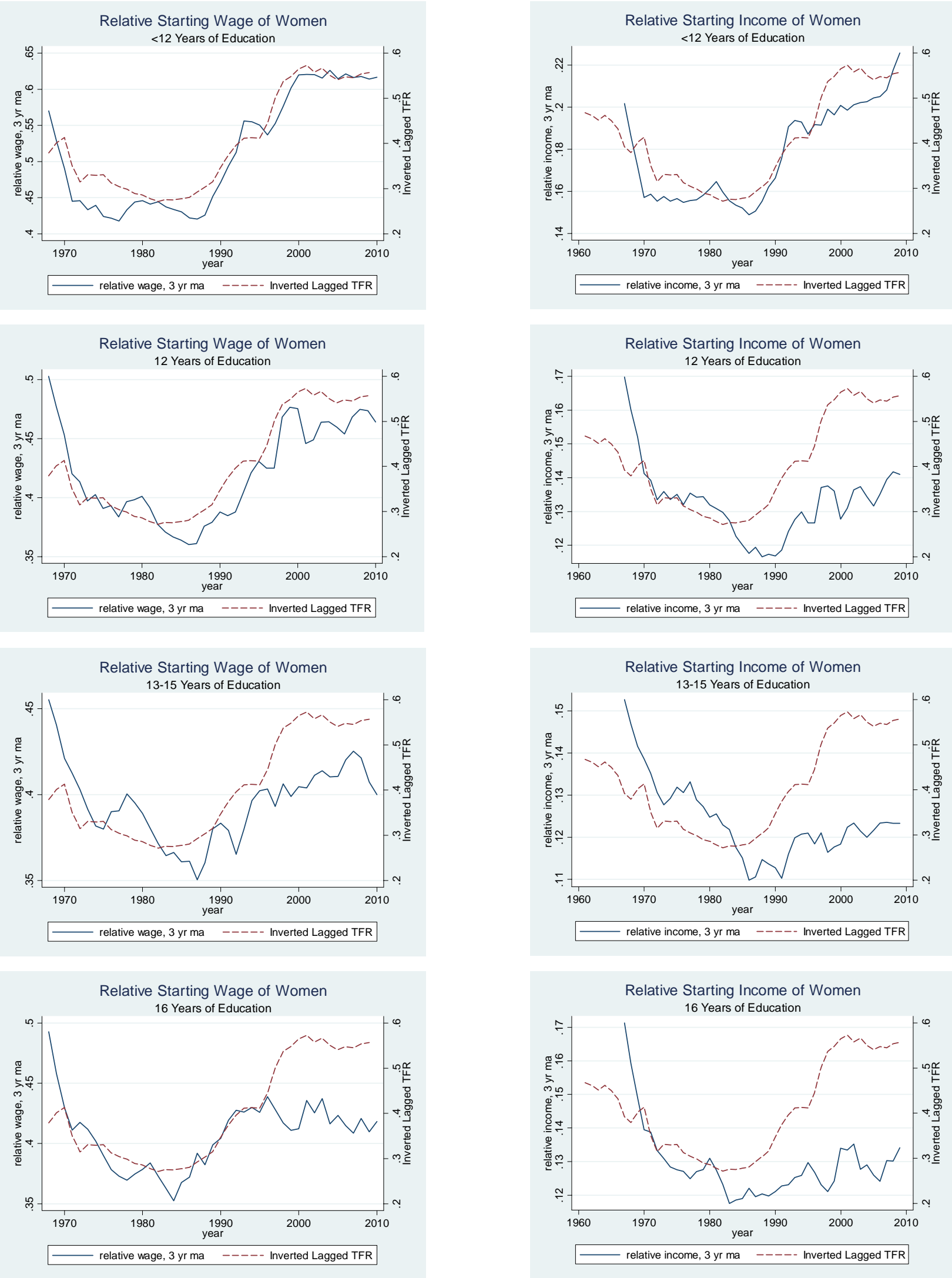
Figure 4: Patterns of Fertility 1968 - 2010 (3-yr moving averages)
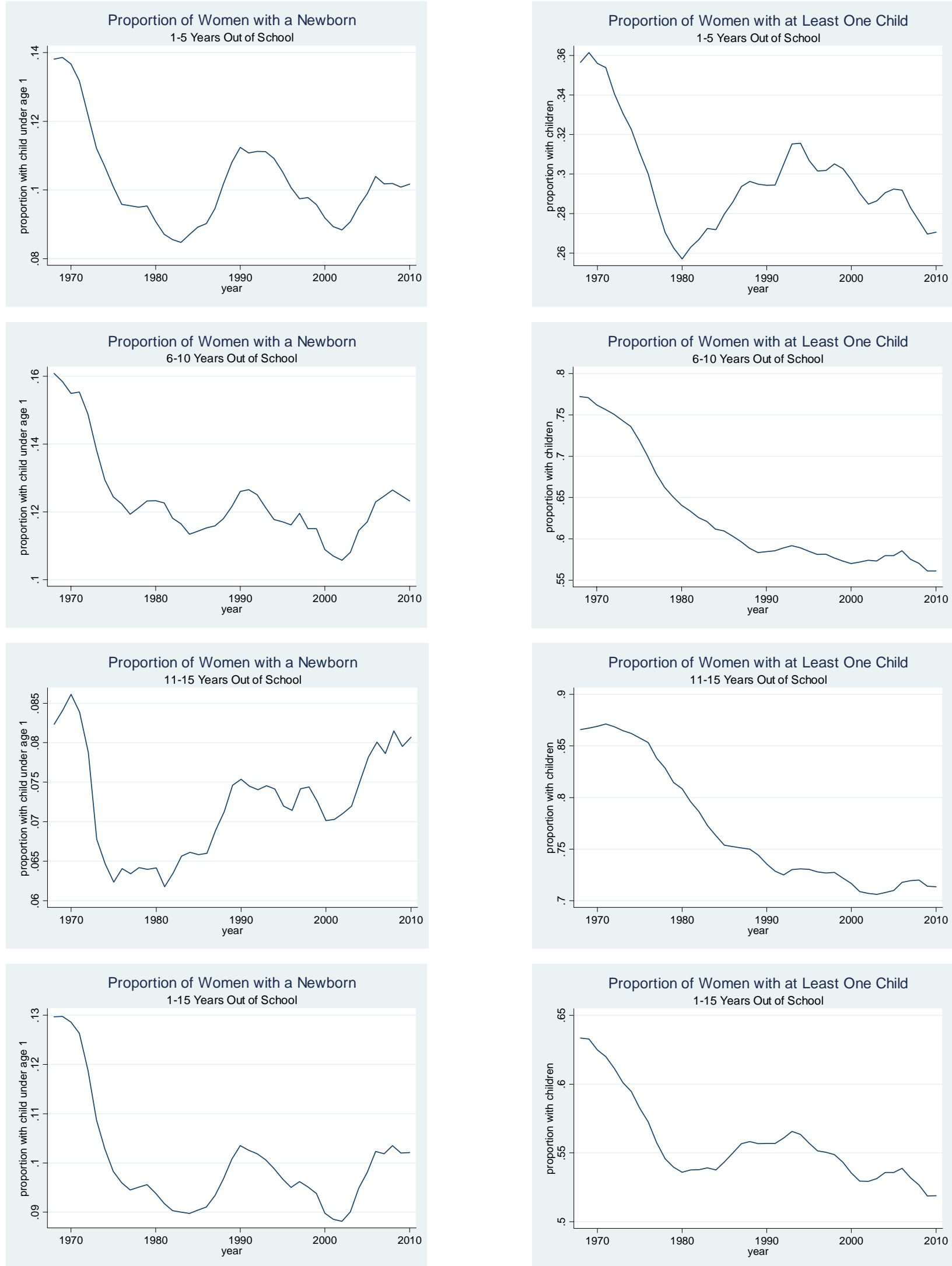
Table 1: Summary Statistics - Means and Standard Deviations

\begin{tabular}{|l|l|c|c|c|c|}
\hline \multicolumn{2}{|c|}{} & 1968 & 1990 & 2000 & 2010 \\
\hline \multicolumn{7}{|l|}{ Proportion with one child under one year of age, by years out of school: } \\
\hline & $0-5$ & $.134(.24)$ & $.122(.27)$ & $.098(.25)$ & $.099(.23)$ \\
\hline & $6-10$ & $.165(.27)$ & $.133(.26)$ & $.116(.26)$ & $.122(.25)$ \\
\hline & $11-15$ & $.088(.21)$ & $.073(.19)$ & $.065(.19)$ & $.071(.19)$ \\
\hline & all & $.134(.12)$ & $.105(.26)$ & $.091(.25)$ & $.100(.25)$ \\
\hline
\end{tabular}

Proportion with at least one child by years out of school:

\begin{tabular}{|l|l|l|l|l|l|}
\hline & $0-5$ & $.369(.37)$ & $.314(.39)$ & $.311(.39)$ & $.287(.37)$ \\
\hline & $6-10$ & $.755(.32)$ & $.607(.33)$ & $.589(.39)$ & $.591(.38)$ \\
\hline & $11-15$ & $.842(.29)$ & $.740(.33)$ & $.715(.36)$ & $.728(.34)$ \\
\hline & all & $.641(.44)$ & $.555(.54)$ & $.536(.45)$ & $.518(.44)$ \\
\hline
\end{tabular}

Male wage by years out of school:

\begin{tabular}{|l|l|l|l|l|l|}
\hline & $0-5$ & $15.3(8.4)$ & $14.7(10.0)$ & $15.7(11.8)$ & $17.4(15.4)$ \\
\hline & $6-10$ & $18.3(7.5)$ & $19.0(10.7)$ & $21.0(14.3)$ & $21.9(16.5)$ \\
\hline & $11-15$ & $19.9(10.2)$ & $21.9(11.4)$ & $23.6(16.5)$ & $26.2(21.9)$ \\
\hline & all & $17.6(9.0)$ & $18.3(11.1)$ & $19.9(14.6)$ & $21.7(18.5)$ \\
\hline
\end{tabular}

Female starting wage by years of schooling:

\begin{tabular}{|l|l|c|c|c|c|}
\hline & $<12$ & $9.0(5.6)$ & $8.2(6.7)$ & $11.7(13.0)$ & $10.1(7.6)$ \\
\hline & 12 & $9.8(3.5)$ & $9.4(6.2)$ & $10.4(8.0)$ & $8.9(3.5)$ \\
\hline & $>12$ & $14.9(10.0)$ & $12.9(11.3)$ & $16.2(16.7)$ & $15.5(12.6)$ \\
\hline & all & $12.0(8.2)$ & $10.9(9.5)$ & $13.7(14.4)$ & $12.9(10.7)$ \\
\hline
\end{tabular}

Older family income by years of schooling (000's):

\begin{tabular}{|l|l|c|c|c|c|}
\hline & $<12$ & $42.2(14.7)$ & $47.7(25.4)$ & $42.4(22.0)$ & $39.9(21.8)$ \\
\hline & 12 & $57.0(18.0)$ & $70.7(24.2)$ & $65.6(23.4)$ & $62.8(23.3)$ \\
\hline & $>12$ & $82.2(29.4)$ & $108.7(44.8)$ & $113.7(46.8)$ & $104.7(51.0)$ \\
\hline & all & $62.1(29.0)$ & $81.5(45.2)$ & $86.1(49.1)$ & $81.0(49.6)$ \\
\hline
\end{tabular}

Standard deviations in parentheses. 


\begin{tabular}{|c|c|c|c|c|c|c|c|c|}
\hline \multirow[b]{2}{*}{ \# of Observations } & \multicolumn{5}{|c|}{$0-5$ years out of school } & \multirow{2}{*}{$\begin{array}{c}\text { 6-10 years } \\
33665\end{array}$} & \multirow{2}{*}{$\begin{array}{c}\text { 11-15 years } \\
28378\end{array}$} & \multirow{2}{*}{$\begin{array}{c}\text { 0-15 years } \\
107998\end{array}$} \\
\hline & 45955 & 45955 & 45955 & 45955 & 45955 & & & \\
\hline Adj. R-Square & 0.3571 & 0.3585 & 0.3587 & 0.3587 & 0.359 & 0.1985 & 0.0726 & 0.5209 \\
\hline Male Expected Wage & $\begin{array}{l}0.000 \\
(0.1)\end{array}$ & $\begin{array}{c}0.002 \\
(0.4)\end{array}$ & $\begin{array}{c}0.001 \\
(0.2)\end{array}$ & $\begin{array}{c}0.002 \\
(0.3)\end{array}$ & $\begin{array}{c}0.007 \\
(1.0)\end{array}$ & $\begin{array}{c}0.004 \\
(0.6)\end{array}$ & $\begin{array}{l}0.016 \\
(1.5)\end{array}$ & $\begin{array}{c}0.011 \\
(2.9)\end{array}$ \\
\hline Female Starting Wage & $\begin{array}{c}0.001 \\
(0.2)\end{array}$ & $\begin{array}{c}0.005 \\
(0.8)\end{array}$ & $\begin{array}{c}0.006 \\
(1.0)\end{array}$ & $\begin{array}{c}0.024 \\
(1.6)\end{array}$ & $\begin{array}{c}0.031 \\
(2.0)\end{array}$ & $\begin{array}{c}-0.072 \\
(-2.9)\end{array}$ & $\begin{array}{c}-0.163 \\
(-4.5)\end{array}$ & $\begin{array}{c}-0.047 \\
(-4.6)\end{array}$ \\
\hline Older family income & & $\begin{array}{c}-0.075 \\
(-8.9)\end{array}$ & $\begin{array}{c}-0.066 \\
(-7.5)\end{array}$ & $\begin{array}{c}-0.064 \\
(-7.3)\end{array}$ & $\begin{array}{c}-0.063 \\
(-7.2)\end{array}$ & $\begin{array}{c}-0.025 \\
(-2.3)\end{array}$ & $\begin{array}{c}-0.026 \\
(-2.1)\end{array}$ & $\begin{array}{c}-0.038 \\
(-7.8)\end{array}$ \\
\hline Time & & & $\begin{array}{l}-0.016 \\
(-3.2)\end{array}$ & $\begin{array}{c}-0.001 \\
(-0.1)\end{array}$ & $\begin{array}{c}-0.001 \\
(-0.1)\end{array}$ & $\begin{array}{l}-0.127 \\
(-8.6)\end{array}$ & $\begin{array}{c}-0.125 \\
(-8.1)\end{array}$ & $\begin{array}{c}-0.068 \\
(-9.9)\end{array}$ \\
\hline Time*Female wage & & & & $\begin{array}{c}-0.026 \\
(-1.3)\end{array}$ & $\begin{array}{c}-0.023 \\
(-1.2)\end{array}$ & $\begin{array}{l}0.100 \\
(3.4)\end{array}$ & $\begin{array}{c}0.205 \\
(5.2)\end{array}$ & $\begin{array}{c}0.061 \\
(4.9)\end{array}$ \\
\hline Q1*Female wage & & & & & $\begin{array}{l}0.007 \\
(1.1)\end{array}$ & $\begin{array}{l}0.012 \\
(1.8)\end{array}$ & $\begin{array}{c}0.004 \\
(0.5)\end{array}$ & $\begin{array}{c}0.010 \\
(2.9)\end{array}$ \\
\hline Q2*Female wage & & & & & $\begin{array}{c}0.002 \\
(0.4)\end{array}$ & $\begin{array}{l}0.000 \\
(0.1)\end{array}$ & $\begin{array}{c}0.000 \\
(0.0)\end{array}$ & $\begin{array}{c}0.003 \\
(1.0)\end{array}$ \\
\hline Q4*Female wage & & & & & $\begin{array}{c}-0.018 \\
(-3.1)\end{array}$ & $\begin{array}{c}-0.001 \\
(-0.1)\end{array}$ & $\begin{array}{c}-0.012 \\
(-1.2)\end{array}$ & $\begin{array}{c}-0.005 \\
(-1.4)\end{array}$ \\
\hline Q5*Female wage & & & & & $\begin{array}{c}-0.013 \\
(-1.9)\end{array}$ & $\begin{array}{c}-0.012 \\
(-1.0)\end{array}$ & $\begin{array}{c}-0.035 \\
(-2.1)\end{array}$ & $\begin{array}{l}-0.007 \\
(-1.5)\end{array}$ \\
\hline Black? & $\begin{array}{l}0.115 \\
(22.8)\end{array}$ & $\begin{array}{l}0.099 \\
(18.4)\end{array}$ & $\begin{array}{l}0.101 \\
(18.8)\end{array}$ & $\begin{array}{l}0.102 \\
(18.8)\end{array}$ & $\begin{array}{l}0.103 \\
(19.0)\end{array}$ & $\begin{array}{l}0.051 \\
(7.9)\end{array}$ & $\begin{array}{c}0.013 \\
(1.8)\end{array}$ & $\begin{array}{l}0.051 \\
(17.4)\end{array}$ \\
\hline Other non-white? & $\begin{array}{l}-0.005 \\
(-1.3)\end{array}$ & $\begin{array}{c}-0.008 \\
(-2.0)\end{array}$ & $\begin{array}{c}-0.006 \\
(-1.6)\end{array}$ & $\begin{array}{l}-0.006 \\
(-1.5)\end{array}$ & $\begin{array}{c}-0.006 \\
(-1.5)\end{array}$ & $\begin{array}{c}-0.003 \\
(-0.5)\end{array}$ & $\begin{array}{c}-0.013 \\
(-1.8)\end{array}$ & $\begin{array}{c}-0.006 \\
(-2.5)\end{array}$ \\
\hline Years of schooling: & & & & & & & & \\
\hline$<8$ ? & $\begin{array}{l}0.026 \\
(6.2)\end{array}$ & $\begin{array}{c}0.021 \\
(5.0)\end{array}$ & $\begin{array}{l}0.021 \\
(5.1)\end{array}$ & $\begin{array}{c}0.021 \\
(5.2)\end{array}$ & $\begin{array}{c}0.022 \\
(5.3)\end{array}$ & $\begin{array}{l}0.022 \\
(4.2)\end{array}$ & $\begin{array}{l}0.013 \\
(2.3)\end{array}$ & $\begin{array}{c}0.014 \\
(6.4)\end{array}$ \\
\hline $8-11 ?$ & $\begin{array}{l}0.136 \\
(26.6)\end{array}$ & $\begin{array}{l}0.122 \\
(22.8)\end{array}$ & $\begin{array}{l}0.123 \\
(23.0)\end{array}$ & $\begin{array}{l}0.124 \\
(23.0)\end{array}$ & $\begin{array}{l}0.127 \\
(23.1)\end{array}$ & $\begin{array}{l}0.130 \\
(21.8)\end{array}$ & $\begin{array}{l}0.077 \\
(11.1)\end{array}$ & $\begin{array}{l}0.092 \\
(32.7)\end{array}$ \\
\hline $13-15 ?$ & $\begin{array}{l}-0.063 \\
(-12.8)\end{array}$ & $\begin{array}{r}-0.047 \\
(-9.0)\end{array}$ & $\begin{array}{c}-0.047 \\
(-8.9)\end{array}$ & $\begin{array}{c}-0.048 \\
(-9.1)\end{array}$ & $\begin{array}{c}-0.048 \\
(-9.0)\end{array}$ & $\begin{array}{c}-0.048 \\
(-7.0)\end{array}$ & $\begin{array}{c}-0.010 \\
(-1.2)\end{array}$ & $\begin{array}{l}-0.031 \\
(-10.4)\end{array}$ \\
\hline $16 ?$ & $\begin{array}{l}-0.217 \\
(-41.5)\end{array}$ & $\begin{array}{l}-0.174 \\
(-25.0)\end{array}$ & $\begin{array}{l}-0.176 \\
(-25.2)\end{array}$ & $\begin{array}{l}-0.179 \\
(-24.9)\end{array}$ & $\begin{array}{l}-0.175 \\
(-23.8)\end{array}$ & $\begin{array}{l}-0.182 \\
(-18.4)\end{array}$ & $\begin{array}{c}-0.106 \\
(-9.1)\end{array}$ & $\begin{array}{l}-0.129 \\
(-31.1)\end{array}$ \\
\hline$>16 ?$ & $\begin{array}{l}-0.076 \\
(-15.3)\end{array}$ & $\begin{array}{c}-0.042 \\
(-6.8)\end{array}$ & $\begin{array}{c}-0.045 \\
(-7.2)\end{array}$ & $\begin{array}{c}-0.046 \\
(-7.3)\end{array}$ & $\begin{array}{c}-0.043 \\
(-6.7)\end{array}$ & $\begin{array}{c}-0.084 \\
(-8.6)\end{array}$ & $\begin{array}{c}-0.071 \\
(-6.1)\end{array}$ & $\begin{array}{l}-0.052 \\
(-13.1)\end{array}$ \\
\hline
\end{tabular}




\begin{tabular}{|c|c|c|c|c|c|c|c|}
\hline \multirow[b]{2}{*}{ \# of Observations } & \multicolumn{4}{|c|}{$0-5$ years out of school } & \multirow{2}{*}{$\begin{array}{c}\text { 6-10 years } \\
33665\end{array}$} & \multirow{2}{*}{$\begin{array}{c}11-15 \text { years } \\
28378\end{array}$} & \multirow{2}{*}{$\begin{array}{c}0-15 \text { years } \\
107998\end{array}$} \\
\hline & 45955 & 45955 & 45955 & 45955 & & & \\
\hline Adj. R-Square & 0.0742 & 0.0748 & 0.0748 & 0.0749 & 0.0115 & 0.0297 & 0.0476 \\
\hline Male expected wage & $\begin{array}{l}0.008 \\
(1.2)\end{array}$ & $\begin{array}{l}0.009 \\
(1.3)\end{array}$ & $\begin{array}{c}0.008 \\
(1.2)\end{array}$ & $\begin{array}{l}0.009 \\
(1.4)\end{array}$ & $\begin{array}{l}0.001 \\
(0.2)\end{array}$ & $\begin{array}{c}0.018 \\
(1.9)\end{array}$ & $\begin{array}{c}0.023 \\
(5.2)\end{array}$ \\
\hline Female starting wage & $\begin{array}{c}0.008 \\
(1.4)\end{array}$ & $\begin{array}{c}0.011 \\
(1.8)\end{array}$ & $\begin{array}{c}0.011 \\
(1.9)\end{array}$ & $\begin{array}{c}0.040 \\
(2.3)\end{array}$ & $\begin{array}{c}-0.066 \\
(-2.2)\end{array}$ & $\begin{array}{c}-0.071 \\
(-1.7)\end{array}$ & $\begin{array}{l}-0.042 \\
(-2.8)\end{array}$ \\
\hline Older family income & & $\begin{array}{c}-0.046 \\
(-4.8)\end{array}$ & $\begin{array}{c}-0.041 \\
(-4.0)\end{array}$ & $\begin{array}{c}-0.038 \\
(-3.7)\end{array}$ & $\begin{array}{r}-0.007 \\
(-0.6)\end{array}$ & $\begin{array}{c}0.010 \\
(0.8)\end{array}$ & $\begin{array}{c}-0.021 \\
(-3.2)\end{array}$ \\
\hline Time & & & $\begin{array}{l}-0.009 \\
(-1.6)\end{array}$ & $\begin{array}{c}0.014 \\
(1.0)\end{array}$ & $\begin{array}{c}-0.044 \\
(-2.6)\end{array}$ & $\begin{array}{c}0.015 \\
(0.9)\end{array}$ & $\begin{array}{c}-0.034 \\
(-3.5)\end{array}$ \\
\hline Time*Female wage & & & & $\begin{array}{r}-0.040 \\
(-1.8)\end{array}$ & $\begin{array}{c}0.100 \\
(2.9)\end{array}$ & $\begin{array}{c}0.084 \\
(2.0)\end{array}$ & $\begin{array}{c}0.069 \\
(3.9)\end{array}$ \\
\hline Black? & $\begin{array}{c}-0.005 \\
(-0.9)\end{array}$ & $\begin{array}{c}-0.015 \\
(-2.5)\end{array}$ & $\begin{array}{l}-0.013 \\
(-2.2)\end{array}$ & $\begin{array}{c}-0.013 \\
(-2.1)\end{array}$ & $\begin{array}{c}-0.051 \\
(-7.8)\end{array}$ & $\begin{array}{c}-0.034 \\
(-4.6)\end{array}$ & $\begin{array}{c}-0.029 \\
(-7.6)\end{array}$ \\
\hline Other non-white? & $\begin{array}{l}-0.010 \\
(-2.2)\end{array}$ & $\begin{array}{l}-0.012 \\
(-2.6)\end{array}$ & $\begin{array}{l}-0.011 \\
(-2.3)\end{array}$ & $\begin{array}{l}-0.010 \\
(-2.2)\end{array}$ & $\begin{array}{l}-0.008 \\
(-1.3)\end{array}$ & $\begin{array}{l}-0.010 \\
(-1.3)\end{array}$ & $\begin{array}{l}-0.008 \\
(-2.3)\end{array}$ \\
\hline Years of schooling: & & & & & & & \\
\hline$<8 ?$ & $\begin{array}{l}0.027 \\
(4.1)\end{array}$ & $\begin{array}{l}0.023 \\
(3.6)\end{array}$ & $\begin{array}{c}0.024 \\
(3.6)\end{array}$ & $\begin{array}{c}0.024 \\
(3.7)\end{array}$ & $\begin{array}{l}0.026 \\
(3.9)\end{array}$ & $\begin{array}{c}0.033 \\
(4.2)\end{array}$ & $\begin{array}{c}0.026 \\
(6.4)\end{array}$ \\
\hline 8-11? & $\begin{array}{l}0.084 \\
(13.7)\end{array}$ & $\begin{array}{l}0.075 \\
(11.8)\end{array}$ & $\begin{array}{l}0.076 \\
(11.9)\end{array}$ & $\begin{array}{l}0.077 \\
(12.0)\end{array}$ & $\begin{array}{c}0.043 \\
(5.9)\end{array}$ & $\begin{array}{c}0.034 \\
(4.4)\end{array}$ & $\begin{array}{l}0.061 \\
(14.6)\end{array}$ \\
\hline $13-15 ?$ & $\begin{array}{l}-0.047 \\
(-8.3)\end{array}$ & $\begin{array}{l}-0.037 \\
(-6.2)\end{array}$ & $\begin{array}{l}-0.037 \\
(-6.2)\end{array}$ & $\begin{array}{c}-0.039 \\
(-6.4)\end{array}$ & $\begin{array}{c}-0.010 \\
(-1.3)\end{array}$ & $\begin{array}{l}-0.010 \\
(-1.2)\end{array}$ & $\begin{array}{c}-0.022 \\
(-5.6)\end{array}$ \\
\hline $16 ?$ & $\begin{array}{l}-0.117 \\
(-19.8)\end{array}$ & $\begin{array}{l}-0.091 \\
(-11.4)\end{array}$ & $\begin{array}{l}-0.092 \\
(-11.5)\end{array}$ & $\begin{array}{l}-0.096 \\
(-11.7)\end{array}$ & $\begin{array}{l}0.024 \\
(2.3)\end{array}$ & $\begin{array}{c}0.000 \\
(0.0)\end{array}$ & $\begin{array}{c}-0.035 \\
(-6.4)\end{array}$ \\
\hline$>16 ?$ & $\begin{array}{l}-0.037 \\
(-6.5)\end{array}$ & $\begin{array}{l}-0.016 \\
(-2.3) \\
\end{array}$ & $\begin{array}{c}-0.018 \\
(-2.5) \\
\end{array}$ & $\begin{array}{l}-0.020 \\
(-2.8) \\
\end{array}$ & $\begin{array}{c}0.010 \\
(1.0)\end{array}$ & $\begin{array}{c}-0.038 \\
(-3.4) \\
\end{array}$ & $\begin{array}{c}-0.016 \\
(-3.0) \\
\end{array}$ \\
\hline
\end{tabular}

